\title{
Metastasectomy Improves Survival in Patients with Metastatic Urothelial Carcinoma
}

\author{
HIROAKI IWAMOTO ${ }^{1}$, KOUJI IZUMI $^{1}$, YUSUKE SHIMURA ${ }^{2}$, ARIUNBOLD NATSAGDORJ ${ }^{1}$, \\ AERKEN MAOLAKE ${ }^{1}$, YUTA TAKEZAWA ${ }^{1}$, TAKAHIRO NOHARA ${ }^{1}$, \\ KAZUYOSHI SHIGEHARA ${ }^{1}$, YOSHIFUMI KADONO ${ }^{1}$ and ATSUSHI MIZOKAMI ${ }^{1}$ \\ ${ }^{1}$ Department of Integrative Cancer Therapy and Urology, \\ Kanazawa University Graduate School of Medical Science, Kanazawa, Japan; \\ ${ }^{2}$ Department of Hospital Pharmacy, Kanazawa University Hospital, Kanazawa, Japan
}

\begin{abstract}
Metastatic urothelial carcinoma is one of the most fatal urological malignancies. Cisplatin-based systemic chemotherapy is the standard treatment for metastatic urothelial carcinoma, and there is little evidence to support metastasectomy. The aims of the study were to evaluate the efficacy of metastasectomy and to investigate the prognoses of the patients. The study included 436 patients with urothelial carcinoma who were treated at our hospital. Of these, we included and retrospectively analyzed 29 patients who received curative treatment for the primary tumor and had been treated for metastases. Seven of these patients underwent metastasectomy. In a multivariate analysis, a serum $C$-reactive protein level before treatment for metastasis of $<1 \quad \mathrm{mg} / \mathrm{dl}$ and metastasectomy were independent significant predictors of both better progressionfree survival and better overall survival. Metastasectomy may be considered a potential treatment for patients with metastases from urothelial carcinoma.
\end{abstract}

Metastatic urothelial carcinoma (mUC) is considered an incurable disease. Systemic chemotherapy is the mainstay of treatment for mUC. Although the initial response rate of cisplatin-based combination chemotherapy is highly effective (45-70\%) (1-3), these responses are transient, and few patients achieve long-term survival. Therefore, several investigators introduced the concept of surgical resection of metastases to improve survival (4-9). However, the role of

Correspondence to: Kouji Izumi, Department of Integrative Cancer Therapy and Urology, Kanazawa University Graduate School of Medical Science, 13-1 Takara-machi, Kanazawa, Ishikawa 9208641, Japan. Tel: +81 762652393, Fax: +81 762344263, e-mail: azuizu2003@yahoo.co.jp

Key Words: Metastasectomy, metastasis, overall survival, progressionfree survival, urothelial carcinoma. metastasectomy and its impact on survival remains controversial. In this study, we retrospectively examined the role of metastasectomy and prognostic factors after the initiation of treatment for mUC.

\section{Patients and Methods}

Between October 2007 and December 2015, 436 patients with UC were treated at our hospital. Patients without histologically confirmed urothelial cancer, without metastases, and without curative treatment for the primary tumor and metastases were excluded from this study. Consequently, 29 patients met the inclusion criteria and were retrospectively analyzed. The demographic, surgical, pathological, and follow-up data were retrospectively collected from their medical charts. The follow-up period was closed on March 10, 2016. During the study period, all therapeutic decisions were left to the discretion of each attending physician. Although there were no prospective criteria, metastasectomy was considered when the patients had metastasis in a single organ with a small number of metastases or a good performance status (PS). Disease status was generally re-evaluated using a chest X-ray or computed tomography (CT) of the chest, abdomen, and pelvis every 3 to 6 months.

Survival was measured from the initiation of mUC treatment or the time of metastasectomy until death or the last follow-up. Progression-free survival (PFS) and overall survival (OS) were estimated using the Kaplan-Meier method. The Cox proportional hazard model was used for the multivariate analyses. Log-rank tests were used for the comparison of the survival distributions. Statistical analyses were performed using commercially available software SPSS software, version 17.0 (SPSS Inc., Chicago, IL, USA) and Prism (GraphPad, San Diego, CA, USA). In all analyses, a $p$-value of less than 0.05 was taken to indicate statistical significance.

\section{Results}

The patient characteristics are shown in Table I. The median age at the start of the treatment of metastases was 74 years (range: 58-93). Twenty-two patients underwent resection of the primary site. Lymph nodes were the most 
Table I. Patient characteristics.

\begin{tabular}{lc}
\hline Characteristic & \\
\hline Median age (range), years & $74(58-93)$ \\
Total, $\mathrm{n}$ & 29 \\
Male & 19 \\
Female & 10 \\
Primary site, $\mathrm{n}$ & \\
Bladder & 16 \\
Upper urinary tract & 10 \\
Both & 3 \\
Resection of primary site, $\mathrm{n}$ & \\
Yes & 22 \\
No & 7 \\
Metastatic site, $\mathrm{n}$ & \\
Lymph node & 19 \\
$\quad$ Regional lymph node & 13 \\
$\quad$ Distant lymph node & 9 \\
Lung & 6 \\
Liver & 4 \\
Bone & 2 \\
Brain & 1 \\
Local recurrence, $\mathrm{n}$ & 1 \\
Resection of metastasis, $\mathrm{n}$ & \\
Yes & 22 \\
No & \\
\hline
\end{tabular}

frequent metastatic site $(19 / 22,65.5 \%)$. There was a single metastasis in 11 patients, and two or more metastases in 18 patients. Seven out of the 29 patients underwent metastasectomy.

Table II shows the clinical courses for each patients who underwent metastasectomy. Six patients had a single metastasis and underwent initial metastasectomy, and one patient had innumerable metastases and underwent two courses of cisplatin-based chemotherapy first before metastasectomy. A lobectomy for lung metastasis was performed in four patients, lymphadenectomy for lymph node metastasis was performed in two patients, and resection of a metastatic brain tumor was performed in one patient. All patients had pathologically viable cancer cells. After the metastasectomy, recurrence occurred in five patients, two of whom underwent repeat metastasectomy.

Table III shows the results of the univariate and multivariate analyses for prognostic significance after the treatment of metastases. In the multivariate analyses, independent significant predictors of better PFS were a pathological grade of 1 or 2 , single-site metastasis, a serum C-reactive protein (CRP) before treatment for metastasis of $<1 \mathrm{mg} / \mathrm{dl}$, and undergoing metastasectomy. Moreover, a CRP of $<1 \mathrm{mg} / \mathrm{dl}$ and undergoing metastasectomy were independent significant predictors of a better OS. The Kaplan-Meier survival curves of PFS and OS by independent significant predictors are shown in Figures 1 and 2 .

Table II. Clinical courses of the seven patients who underwent metastasectomy.

\begin{tabular}{|c|c|c|c|c|c|c|c|c|c|c|c|}
\hline Patient & $\begin{array}{l}\text { Age, } \\
\text { years }\end{array}$ & Gender & Origin & $\begin{array}{c}\text { Metastatic } \\
\text { site }\end{array}$ & $\begin{array}{l}\text { Treatment of } \\
\text { primary site }\end{array}$ & $\begin{array}{l}\text { Metastasectomy/ } \\
\text { pathology }\end{array}$ & $\begin{array}{l}\text { Adjuvant } \\
\text { CTx }\end{array}$ & Recurrence & $\begin{array}{c}\text { Repeat } \\
\text { metastasectomy }\end{array}$ & $\begin{array}{l}\text { Further } \\
\text { CTx }\end{array}$ & $\begin{array}{c}\text { Follow up } \\
\text { (months), } \\
\text { outcome }\end{array}$ \\
\hline 1 & 72 & Male & $\mathrm{B}$ & Lung & $\begin{array}{l}\text { MVAC } \times 2+ \\
\text { radical } \\
\text { cystectomy }\end{array}$ & $\begin{array}{l}\text { Lobectomy/ } \\
\text { viable }\end{array}$ & Gcarbo $\times 3$ & Lung & Lobectomy & None & $33.1, \mathrm{CD}$ \\
\hline 2 & 76 & Male & B & $\begin{array}{l}\text { Distant } \\
\text { LN }\end{array}$ & Radiation & $\begin{array}{l}\text { Lymphadenectomy/ } \\
\text { viable }\end{array}$ & $\mathrm{GC} \times 2$ & - & None & None & 16.8, NED \\
\hline 3 & 62 & Male & $\mathrm{U}$ & $\begin{array}{c}\text { Br, } \\
\text { Resional } \\
\text { LN }\end{array}$ & $\begin{array}{c}\text { Partial } \\
\text { ureterectomy }\end{array}$ & $\begin{array}{c}\text { Resection of } \\
\text { metastatic brain } \\
\text { tumor/viable }\end{array}$ & $\begin{array}{c}\mathrm{GC} \times 2, \mathrm{UFT}, \\
\mathrm{GC} \times 5, \\
\text { Tcarbo } \times 2\end{array}$ & LN & None & None & $20.5, \mathrm{CD}$ \\
\hline 4 & 60 & Male & B & Lung & $\begin{array}{l}\text { Radical } \\
\text { cystectomy } \\
+\mathrm{GC} \times 2 *\end{array}$ & Lobectomy/viable & None & Lung, LN & None & $\begin{array}{l}\text { GC } \times 1, \\
\text { Tcarbo } \times 1\end{array}$ & 49.5, CD \\
\hline 5 & 67 & Male & B & $\begin{array}{l}\text { Distant } \\
\text { LN }\end{array}$ & $\begin{array}{c}\text { Radical } \\
\text { cystectomy }\end{array}$ & $\begin{array}{l}\text { Lymphadenectomy/ } \\
\text { viable }\end{array}$ & None & Lung & None & $\begin{array}{c}\text { MVAC } \times 3, \\
\text { UFT }\end{array}$ & 37.1, AWC \\
\hline 6 & 76 & Female & $\mathrm{U}, \mathrm{B}$ & Lung & $\begin{array}{l}\text { Total nephro } \\
\text { ureterectomy }\end{array}$ & Lobectomy/viable & None & Lung & Lobectomy & UFT & 50, NED \\
\hline 7 & 63 & Male & UUT & Lung & + MVAC $\times 2$ & Lobectomy/viable & $\mathrm{GC} \times 2$ & - & None & None & 9.6, NED \\
\hline
\end{tabular}

CTx: Chemotherapy; B: bladder; U: upper urinary tract; Br: brain; LN: lymph nodes; MVAC: methotrexate + vinblastine + doxorubicin + cisplatin; GC: gemcitabine + cisplatin; Gcarbo: gemcitabine + carboplatin; Tcarbo: paclitaxel + carboplatin; UFT: tegafur uracil; CD: cancer death; NED: no evidence of disease; AWC: alive with cancer. *Induction chemotherapy of methotrexate, vinblastine, doxorubicin and cisplatin was given to this patient but had no effect, no other patient received induction chemotherapy. 
Table III. Results of univariate/multivariate analysis.

\begin{tabular}{|c|c|c|c|c|c|c|c|c|c|c|c|}
\hline \multirow[b]{3}{*}{ Factor } & \multirow[b]{3}{*}{ No } & \multirow[b]{3}{*}{ mPFS (months) } & \multicolumn{4}{|c|}{ PFS } & \multirow[b]{3}{*}{ mOS (months) } & \multicolumn{4}{|c|}{ OS } \\
\hline & & & \multicolumn{2}{|c|}{ Univariate } & \multicolumn{2}{|c|}{ Multivariate } & & \multicolumn{2}{|c|}{ Univariate } & \multicolumn{2}{|c|}{ Multivariate } \\
\hline & & & $p$-Value & HR & $p$-Value & HR & & $p$-Value & HR & $p$-Value & HR \\
\hline Gender & & & 0.269 & 0.626 & & & & 0.641 & 0.807 & & \\
\hline Male & 19 & 5.4 & & & & & 20.5 & & & & \\
\hline Female & 10 & 4.9 & & & & & 15.7 & & & & \\
\hline Age & & & 0.976 & 1.012 & & & & 0.722 & 1.177 & & \\
\hline$<74$ Years & 16 & 4.7 & & & & & 17.1 & & & & \\
\hline$\geq 74$ Years & 13 & 5.4 & & & & & 20.5 & & & & \\
\hline Primary site & & & 0.34 & 1.462 & & & & 0.127 & 2.035 & & \\
\hline Bladder only & 16 & 4.3 & & & & & 11.7 & & & & \\
\hline Other & 13 & 6.6 & & & & & 26 & & & & \\
\hline Primary resection & & & 0.366 & 0.654 & & & & 0.396 & 0.587 & & \\
\hline Yes & 22 & 4.7 & & & & & 17.1 & & & & \\
\hline No & 7 & 5.4 & & & & & UD & & & & \\
\hline Grade & & & 0.04 & 3.745 & 0.003 & 24.61 & & 0.469 & 1.466 & & \\
\hline G1-2 & 5 & 13.5 & & & & & 26.4 & & & & \\
\hline G3 & 22 & 4.7 & & & & & 12.1 & & & & \\
\hline LVI & & & 0.374 & 0.589 & & & & 0.66 & 0.745 & & \\
\hline Yes & 14 & 4.3 & & & & & 14.2 & & & & \\
\hline No & 4 & 7.6 & & & & & 30.2 & & & & \\
\hline Metastasis & & & 0.001 & 4.352 & 0.017 & 3.626 & & 0.019 & 3.257 & 0.055 & 13.594 \\
\hline 1 & 11 & 10.6 & & & & & 33.1 & & & & \\
\hline Many & 18 & 4.3 & & & & & 11.3 & & & & \\
\hline $\mathrm{WBC}, / \mu \mathrm{l}$ & & & 0.895 & 0.921 & & & & 0.344 & 1.834 & & \\
\hline$<8,000$ & 24 & 5.4 & & & & & 20.5 & & & & \\
\hline$\geq 8,000$ & 4 & 7 & & & & & 18.4 & & & & \\
\hline $\mathrm{Hb}, \mathrm{g} / \mathrm{dl}$ & & & 0.374 & 1.435 & & & & 0.096 & 2.211 & & \\
\hline$\geq 11$ & 17 & 5.7 & & & & & 30.2 & & & & \\
\hline$<11$ & 11 & 5 & & & & & 13.8 & & & & \\
\hline CRP, mg/dl & & & 0.036 & 2.545 & 0.017 & 3.626 & & $<0.0001$ & 10.097 & 0.009 & 20.31 \\
\hline$<1$ & 19 & 6.6 & & & & & 30.2 & & & & \\
\hline$\geq 1$ & 8 & 3.9 & & & & & 4.6 & & & & \\
\hline NLR & & & 0.616 & 1.251 & & & & 0.027 & 3.188 & 0.062 & 3.962 \\
\hline$<3$ & 13 & 5.3 & & & & & 30.1 & & & & \\
\hline$\geq 3$ & 10 & 3.6 & & & & & 9.8 & & & & \\
\hline Metastasectomy & & & 0.003 & 5.4 & 0.049 & 6.463 & & 0.026 & 4.3 & 0.009 & 66.19 \\
\hline Yes & 7 & 11.6 & & & & & 41.3 & & & & \\
\hline No & 22 & 3.6 & & & & & 9.8 & & & & \\
\hline
\end{tabular}

mPFS: Median progression-free survival; mOS: median overall survival; LVI: lymphovascular invasion; WBC: white blood cell; Hb: hemoglobin; CRP: C-reactive protein; NLR: neutrophil-to-lymphocyte ratio; UD: Undefined.

\section{Discussion}

In 1982, Cowles et al. first proposed the surgical resection of metastases in the lung, achieving long-term disease control in six patients with mUC (10). Even after radical surgery for a primary tumor, the possibility of recurrence, including distant metastasis, is not uncommon (11). Thereafter, several investigators reported survival outcomes after metastasectomy in patients with $\operatorname{mUC}(4,6,7,9)$. A study including 31 patients who underwent metastasectomy
(77\% for lung metastases) showed a median OS of 23 months and a 5-year OS rate of 33\% (4). A study of metastasectomy for lung metastases reported a 5-year OS rate of $46.5 \%$ in 18 patients (6). These results indicate that metstasectomy of lung lesions should indeed be considered because a previous study had reported a median survival of only 10 months if a metastasectomy was not performed (12).

In 44 patients who underwent the resection of metastatic retroperitoneal lymph nodes (56.8\%) and distant lymph nodes, Lehman et al. reported a median OS of 27-months 

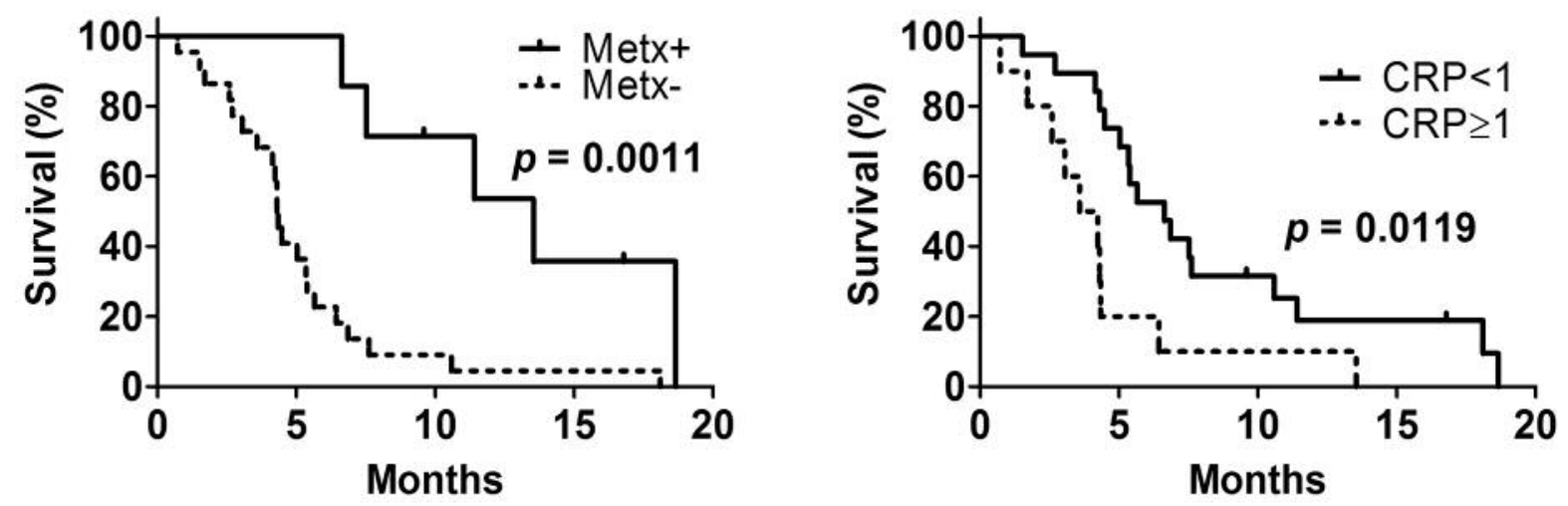

Figure 1. The progression-free survival of the 29 patients according to metastasectomy (Metx; + with, - without) (left) and serum C-reactive protein (CRP) before treatment for metastasis (cut-off of $1 \mathrm{mg} / \mathrm{dl}$ ) (right).
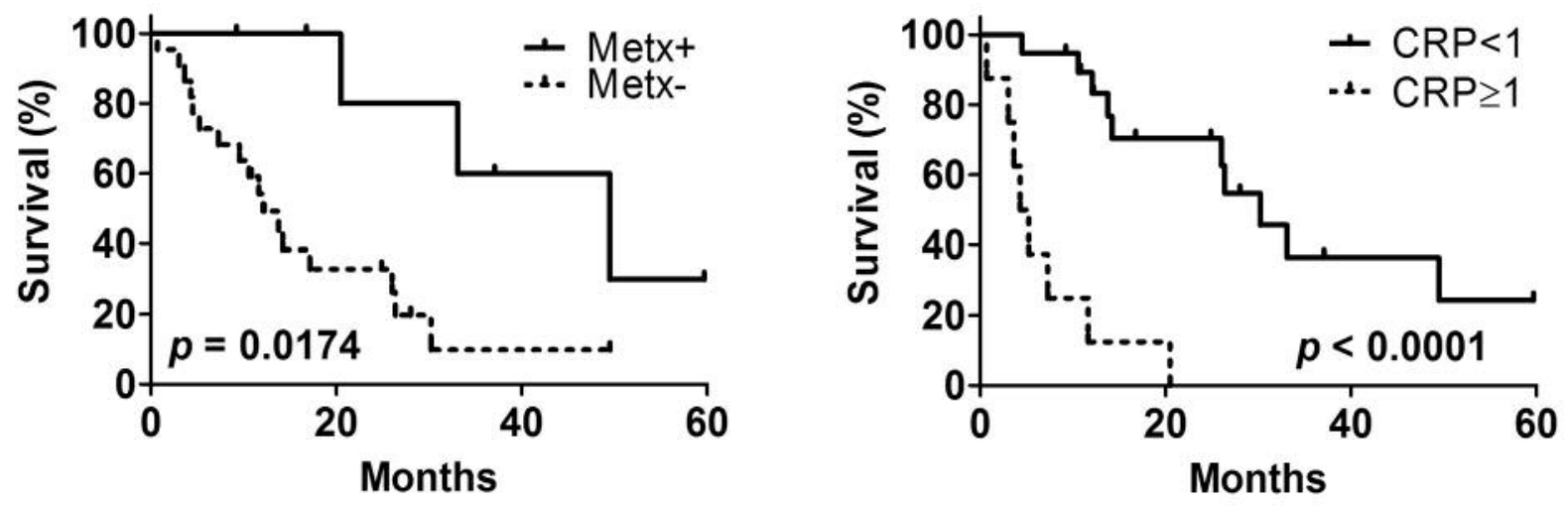

Figure 2. Overall survival of 29 patients according to metastasectomy (Metx; + with, - without) (left) and serum C-reactive protein (CRP) before treatment for metastasis (cut-off of $1 \mathrm{mg} / \mathrm{dl}$ ) (right).

and a $28 \%$ 5-year OS rate (7). This result also indicates the acceptability of metastasectomy for lymph node metastases. Importantly, a study of 42 patients who underwent resection of metastatic lymph nodes (48\%) and lung tumors $(28.6 \%)$ reported results similar to those of the previously mentioned studies, with a 26-month median OS and a 31\% 5-year OS rate (9); these findings indicate the significance of metastasectomy in patients with a solitary lung or solitary lymph node metastasis. In our study, six out of seven patients underwent metastasectomy for either lung or lymph node metastases; therefore, the criteria for metastasectomy with regard to the metastatic site may be reasonable. Interestingly, patients who underwent metastasectomy in our study achieved a median OS of 50 months, and the 5-year OS rate was $30 \%$. The reason for this positive result may be the repeated metastasectomies and the additional chemotherapy administered after metastasectomy, as well as the chemotherapy for the primary site. Otto et al. noted that metastasectomy in patients with mUC refractory to chemotherapy had no survival benefit (13).

In our study, a serum CRP level before treatment for metastasis of $<1 \mathrm{mg} / \mathrm{dl}$ and metastasectomy were independent significant predictors of a prolonged PFS and OS by multivariate analysis. Many investigators have shown that inflammation plays a critical role in tumorigenesis (14). Inflammatory responses contribute both to cancer development and progression and may be associated with systemic inflammation (15). Several studies have demonstrated an association between the CRP level and tumor progression, suggesting that a high CRP level predicts a poor prognosis, as CRP is a non-specific biomarker of systemic inflammation (16-19). Moreover, a meta-analysis showed that serum CRP was an independent prognostic factor in urological cancer (20). Our results were consistent with those findings and increase this evidence. Given these facts, metastasectomy for patients 
with mUC with a CRP $<1 \mathrm{mg} / \mathrm{dl}$ may achieve long-term cancer control.

There remains a question as to whether the small sample size in the present study may have prevented a valid statistically significant determination of the differences between the groups. We believe that larger prospective studies including patients with diverse ethnic backgrounds and longer follow-up periods will be required to confirm our findings. Moreover, treatment with recently developed immune checkpoint inhibitors may also prolong the survival of patients with mUC.

\section{Conclusion}

In this study, we found that a serum CRP level before treatment for metastasis of $<1 \mathrm{mg} / \mathrm{dl}$ and undergoing metastasectomy were independent significant predictors of better PFS and OS in patients with mUC. Patients with a serum CRP level before treatment for metastasis of $<1 \mathrm{mg} / \mathrm{dl}$ may be optimal candidates for metastatectomy for achieving longer survival.

\section{References}

1 von der Maase H, Hansen SW, Roberts JT Dogliotti L, Oliver T, Moore MJ, Bodrogi I, Albers P, Knuth A, Lippert CM, Kerbrat P, Sanchez Rovira P, Wersall P, Cleall SP, Roychowdhury DF, Tomlin I, Visseren-Grul CM and Conte PF: Gemcitabine and cisplatin versus methotrexate, vinblastine, doxorubicin, and cisplatin in advanced or metastatic bladder cancer: results of a large, randomized, multinational, multicenter, phase III study. J Clin Oncol 18(17): 3068-3077, 2000.

2 Sternberg CN, Yagoda A, Scher HI, Watson RC, Ahmed T, Weiselberg LR, Geller N, Hollander PS, Herr HW and Sogani PC: Preliminary results of M-VAC (methotrexate, vinblastine, doxorubicin and cisplatin) for transitional cell carcinoma of the urothelium. J Urol 133(3): 403-407, 1985.

3 Scher HI: Should single agents be standard therapy for urothelial tract tumors? J Clin Oncol 7(6): 694-697, 1989.

4 Siefker-Radtke AO, Walsh GL, Pisters LL, Shen Y, Swanson DA, Logothetis CJ and Millikan RE: Is there a role for surgery in the management of metastatic urothelial cancer? The M. D. Anderson experience. J Urol 171(1): 145-148, 2004.

5 Abe T, Shinohara N, Harabayashi T, Sazawa A, Maruyama S, Suzuki S and Nonomura K: Impact of multimodal treatment on survival in patients with metastatic urothelial cancer. Eur Urol 52(4): 1106-1113, 2007.

6 Kanzaki R, Higashiyama M, Fujiwara A, Tokunaga T, Maeda J, Okami J, Nishimura K and Kodama K: Outcome of surgical resection of pulmonary metastasis from urinary tract transitional cell carcinoma. Interact Cardiovasc Thorac Surg 11(1): 60-64, 2010 .

7 Lehmann J, Suttmann H, Albers P, Volkmer B, Gschwend JE, Fechner G, Spahn M, Heidenreich A, Odenthal A, Seif C, Nürnberg N, Wülfing C, Greb C, Kälble T, Grimm MO, Fieseler CF, Krege S, Retz M, Schulte-Baukloh H, Gerber M, Hack M,
Kamradt $\mathbf{J}$ and Stöckle M: Surgery for metastatic urothelial carcinoma with curative intent: the German experience (AUO AB 30/05). Eur Urol 55(6): 1293-1299, 2009.

8 Matsuguma H, Yoshino I, Ito H, Goya T, Matsui Y, Nakajima J, Ikeda N, Okumura S, Shiono S and Nomori H; Metastatic Lung Tumor Study Group of Japan: Is there a role for pulmonary metastasectomy with a curative intent in patients with metastatic urinary transitional cell carcinoma? Ann Thorac Surg 92(2): 449453, 2011.

9 Abe T, Kitamura H, Obara W, Matsumura N, Matsumura N, Tsukamoto T, Fujioka T, Hara I, Murai S, Shinohara N and Nonomura K: Outcome of metastasectomy for urothelial carcinoma: a multi-institutional retrospective study in Japan. J Urol 191(4): 932-936, 2014.

10 Cowles RS, Johnson DE and McMurtrey MJ: Long-term results following thoracotomy for metastatic bladder cancer. Urology 20(4): 390-392, 1982.

11 Izumi K, Itai S, Takahashi Y, Takahashi R, Maolake A, Ofude M, Ueno S, Kadono Y, Kitagawa Y, Konaka H, Mizokami A and Namiki M: Factors predictive of oncological outcome after nephroureterectomy: comparison between laparoscopic and open procedures. Anticancer Res 33(12): 5501-5506, 2013.

12 Abe T, Shinohara N, Harabayashi T, Sazawa A, Maruyama S, Suzuki S and Nonomura K. Impact of multimodal treatment on survival in patients with metastatic urothelial cancer. Eur Urol 52(4): 11061113, 2007.

13 Otto T, Krege S, Suhr J and Rübben H: Impact of surgical resection of bladder cancer metastases refractory to systemic therapy on performance score: a phase II trial. Urology 57(1): 55-59, 2001.

14 Grivennikov SI, Greten FR and Karin M: Immunity, inflammation, and cancer. Cell 140(6): 883-899, 2010.

15 Aggarwal BB, Vijayalekshmi RV and Sung B: Targeting inflammatory pathways for prevention and therapy of cancer: short-term friend, long-term foe. Clin Cancer Res 15(2): 425430, 2009.

16 Jin Y, Sun Y, Shi X, Zhao J, Shi L and Yu X: Prognostic value of circulating $C$ reactive protein levels in patients with non small cell lung cancer: A systematic review with meta analysis. J Cancer Res Ther 10(Suppl): C160-166, 2014.

17 Singh PP, Zeng ISL, Srinivasa S, Lemanu DP, Connolly AB and Hill AG: Systematic review and meta analysis of use of serum $\mathrm{C}$ reactive protein levels to predict anastomotic leak after colorectal surgery. Br J Surg 101(4): 339-346, 2014.

18 Yi JH, Wang D, Li ZY, Hu J, Niu XF and Liu XL: C reactive protein as a prognostic factor for human osteosarcoma: A meta analysis and literature review. PLoS One 9(5): e94632, 2014.

19 Zheng Z, Zhou L, Gao S, Yang Z, Yao J and Zheng S: Prognostic role of $\mathrm{C}$ reactive protein in hepatocellular carcinoma: A systematic review and meta analysis: Int J Med Sci 10(6): 653-664, 2013.

20 Zhou L, Cai X, Liu Q, Jian ZY, Li H and Wang KJ: Prognostic role of C-reactive protein in urological cancers: A meta-analysis. Sci Rep 5: 12733, 2015.

Received September 7, 2016

Revised September 26, 2016

Accepted September 27, 2016 